\title{
Substrate conditions, root and arbuscular mycorrhizal colonisation of landforms rehabilitated after coal mining, sub-tropical Queensland
}

\author{
A.V. Spain School of Earth and Environment, University of Western Australia \\ M. Tibbett Department of Environmental Science and Technology, Cranfield University, UK
}

\begin{abstract}
The abilities of roots and their mycorrhizal symbionts to colonise often unfavourable materials are critical to successful ecosystem development after mining, both for long-term sustainability and for more immediate erosion control. In this study we examined the capacities of grass roots and their mycorrhizas to colonise successfully a range of soils and post-mining wastes following rehabilitation of landforms constructed after coal mining. Mean soil $\mathrm{pH}$ was slightly acidic and within the normal range for soils $\left(\mathrm{pH}_{(\mathrm{H2O})}\right.$ range ca 5-8) while the wastes were predominantly alkaline and more widely variable $\left(\mathrm{pH}_{(\mathrm{H} 2 \mathrm{O})}\right.$ range ca $\left.4-10\right)$. Soils were non-saline or slightly saline while most wastes were saline or highly saline. Both soils and waste materials were variably sodic. The depth distributions of fine roots and incidences of arbuscular mycorrhizal (AM) colonisation were assessed in the dominant perennial grasses and herbaceous plants in sites rehabilitated for periods ranging from ca 0.3 to 9.4 years. The concentrations of spores of AM fungi in the post mining materials were also assessed. No major barriers to root penetration were apparent in any of the minesoils examined and roots had colonised a range of materials, including some substrates putatively hostile to plant growth. Furthermore, significant mycorrhizal activity was measured in all landforms assessed, despite their lack of inoculation with AM fungi. Arbuscular mycorrhizal spore concentrations were unusually high in some surface soils but declined markedly with depth in the profile. Both AM spores and root colonisation regularly occurred to depths of $1.0 \mathrm{~m}$ or more but the highest concentrations occurred at less than $0.40 \mathrm{~m}$. The consistent colonisation by roots and mycorrhizas of an eclectic range of post-mining soils and wastes demonstrated the innate capacity of (at least) the gross components of the plant-soil system to develop rapidly and extensively in favourable and unfavourable post-mining substrates. Of particular interest was the comprehensive and relatively-rapid natural colonisation by AM fungi of the biologically sterile, and sometimes chemically-hostile mine wastes.
\end{abstract}

\section{Introduction}

The success of rehabilitation works post-mining is a major issue potentially constraining mine closure operations. However, despite the widespread use of phytostabilisation for rehabilitating post-mining landscapes (Weiersbye, 2007), little detailed attention has been paid to the distributions of roots in relation to substrate properties in these artificial landforms. The wastes used to construct post-mining landforms frequently have properties that make them stressful plant growing media: these may include high strength, poor water holding capacity, extreme $\mathrm{pH}$, excessive salinity, high sodicity (see for example, Simon-Coinçon et al., 2003), nutrient deficiencies and imbalances and, at least initially, a lack of mycorrhizal fungi and other biota important in soil development processes. Poor plant performance in growing media with such materials properties can lead to accelerated erosion and impaired landform stability. It is of particular interest to know whether establishment of a plant cover in a limited layer of natural soil materials overlying wastes with stressful properties allows the roots of adapted species and their associated mycorrhizal fungi to penetrate the underlying wastes sufficiently to provide adequate water and nutrient elements. Penetration to depth is necessary to allow the development of a self-sustaining plant cover and to promote the substrate changes necessary for long term pedogenic development of the waste materials (Kulmatiski et al., 2008).

The aims of this paper are to present selected physical, chemical and mineralogical properties of the soils and wastes of five post-mining landforms in relation to the depth distributions of the fine $(<2 \mathrm{~mm}$ diameter) roots of pasture plants, their degree of mycorrhizal colonisation and the occurrence of the spores of arbuscular mycorrhizal (AM) fungi. In particular, we were interested to see if root and mycorrhizal colonisation were 
affected by the period since rehabilitation, depth in the profile and the type of material (soil or mine waste). The present paper forms part of a larger study of mine wastes at Ebenezer Mine (Spain et al., 2010).

\section{Methods}

Ebenezer Mine is located at $27^{\circ} 40^{\prime} \mathrm{S}, 152^{\circ} 40^{\prime} \mathrm{E}$, approximately $44 \mathrm{~km}$ south-west of Brisbane. Mean rainfall is approximately $847 \mathrm{~mm}$ per year with a summer maximum and the climate is subtropical, with no dry season (Bureau of Meteorology, 2011).

The five landforms studied here comprised three rehabilitated waste rock dumps 'Out of Pit' (OP), 'Lane's Dump' (LL), 'O'Connor's Dump' (OC), a 1.9 km-long bund wall (Purga or PU ridge) constructed to isolate mine workings from local inhabitants and an associated artificial flat (Purga or PU flat). The Purga flat landform was created by infilling a pit after mining, restoring drainage pathways and rehabilitating the surface. For all landforms, surface rehabilitation comprised application over the wastes of a layer of stored soil originating from the mixed A and upper B horizons of local natural soils (largely tenosols and sodosols, Isbell, 2002), fertilisation and sowing the plant species listed below.

Three sites studied at the Purga flat site in 1999 remained unsown and unfertilised at the time of the study and supported volunteer vegetation dominated by sparse to isolated forbs and grasses. The four remaining rehabilitated landforms were sown to pasture species: Chloris gayana cv. Finecut, Bothriochloa insculpta cv. Bisset, Digitaria smutsii cv. Premier, Digitaria milanjiana cv Strickland and the N-fixing legumes Macroptilium atropurpureum cv Siratro and Chamaecrista rotundifolia (Anon., 2001).

Description of profiles and sampling of materials was carried out during 1998 and 1999. Pits were dug at 27 locations and profiles described using standard techniques (McDonald and Isbell, 1990). Two profiles had no applied soil layer. Soils and underlying wastes were sampled at measured depths in the profile and materials retained for subsequent analyses. Soil samples intended for chemical analysis were air-dried, sieved $(<2 \mathrm{~mm})$ and sub-samples were stored for analysis. Samples taken for microbiological assessments were maintained at ca $4^{\circ} \mathrm{C}$ until required for analysis.

Particle size distributions (PSD's) of the fine earth $(<2 \mathrm{~mm})$ fraction of the materials were determined using the method of McIntyre and Loveday (Loveday, 1974). Clay minerals were determined using X-ray diffraction (XRD) methods. The $\mathrm{pH}$ and electrical conductivity (EC) were determined on a 1:5 suspension of sample in water (methods 4A1 and 3A1 of Rayment and Higginson, 1992). An estimate of paste EC (ECe) was made by multiplying the EC 1:5 values by values dependent on their field texture (Marcar and Crawford, 2004). Exchangeable sodium percentage (ESP) was calculated as the exchangeable $\mathrm{Na}^{+}$ concentration divided by the effective cation exchange capacity. Total $\mathrm{C}$ and $\mathrm{N}$ concentrations were determined using a Leco frequency induction furnace operated at $1,250^{\circ} \mathrm{C}$. Total $\mathrm{P}$ was determined using X-ray fluorescence (XRF) methods and plant 'available' P using the Olsen method (Rayment and Higginson, 1992). An estimate of readily-mineralisable $\mathrm{N}$ was made using the method of Gianello and Bremner (1986).

Distributions of fine roots ( $<2 \mathrm{~mm}$ diameter), predominantly those of perennial grasses and herbaceous plants, were recorded in 26 soil pits dug in all landforms. Root distributions were assessed using a procedure (McDonald and Isbell, 1990) which comprised making counts of roots present in areas of 100 by $100 \mathrm{~mm}$ demarcated on the pit walls. Roots counted in each square were placed in the following ordered density classes: 0 none; $1,1-10 ; 2,10-25 ; 3,25-200 ; 4,>200$. These counts were made at intervals down the pit walls.

The spores of AM fungi were extracted from the soils and wastes using a combination of wet sieving and differential flotation in sucrose solutions. The percentages of fine root length colonised by AM fungi were determined by clearing the root materials, staining fungal structures with trypan blue and measuring the colonised and total lengths (Bevege, 1968; Tommerup, 1992).

Analysis of variance (ANOVA) was used to determine the significances of differences in chemical and microbiological properties among landforms and between the soils and wastes, nested within landforms. Where overall $\mathrm{F}$ tests proved significant $(\mathrm{P}<0.05)$, Tukey's posterior test was used to determine the significances of sample differences between all pairs of samples, among landforms and between soils and wastes within landforms. Least squares regressions were used to establish depth relationships of chemical and mycorrhizal properties. Appropriate data transformations were used and outlying observations removed 
where required. Ordinal logistic regressions were used to test the relationship between root density classes and depth in the profile, landform age and material type, as predictors. Depth was analysed as three categories: $0-0.49 \mathrm{~m}, 0.50-0.74 \mathrm{~m}, 0.75 \mathrm{~m}$ or greater. Age was analysed as three categories: <1 year, 1-2.9 years, and 3 years or older. Material type was soil (1) or waste (2). Unless otherwise qualified the term 'significant' refers to a test that is significant at $\mathrm{P}=0.05$ or less.

\section{Results}

\subsection{Soil and waste properties}

Profiles comprised a layer of soil over the wastes. Soil thickness in the 25 profiles that had soil cappings did not differ significantly ( $\mathrm{P}>0.05$, one-way ANOVA, $\ln$ transformation) among landforms and mean soil depth over the wastes was $0.31 \mathrm{~m}$ (std dev. 0.15). Two profiles on Lane's Dump had no applied soil layer at the time of sampling. Landform ages ranged from less than one year to more than nine years, with reference to the date of soil application.

Gravel percentages were 2.0\% (std dev. 1.8, $\mathrm{n}=20$ ) in the soils and 3.6\% (std dev. 3.3, $\mathrm{n}=37$ ) in the waste materials from Lane's, O'Connor's and the Out of Pit Dump (Purga landforms not measured). All but a few of the soils and wastes were fine-textured. Mean clay content of the $<2 \mathrm{~mm}$ fraction was $37 \%$ (std dev. 11 , $\mathrm{n}=100$ ); minor differences existed among landforms although differences between soils and wastes were not significant $(\mathrm{P}>0.05)$. The most commonly represented clay-sized minerals were montmorillonite and randomly interstratified smectite-kaolinite; kaolinite was abundant in most materials.

\subsection{1 pH and salinity}

The $\mathrm{pH}_{(\mathrm{H} 20)}$ ranged widely from 3.85 to 9.56 (Figure 1a). A two-way nested ANOVA of landform and material type nested within landform indicated very highly significant $(\mathrm{P}<0.001)$ differences among landforms and between material types nested within landform. Posterior tests indicated an overlapping pattern of non-significant differences among landforms, in which the materials from O'Connor's, Lane's and the Out of Pit Dumps had the lowest $\mathrm{pH}_{(\mathrm{H} 20)}$ values and did not differ significantly $(\mathrm{P}>0.05)$ while the Purga landforms had the highest, again not showing significant variation between the Purga ridge and Purga flat sites. The range of site means among soils was 1.3 units and, among the wastes, 2 units. The $\mathrm{pH}_{(\mathrm{H} 20)}$ values for the wastes were greater than those of the soils at all landforms, except for the Purga flat sites; however, wastes were only significantly $(\mathrm{P}<0.05)$ greater than the soils at the Out of Pit Dump and the Purga ridge sites.

Electrical conductivity ranged broadly from 0.28 to $9.72 \mathrm{dS} \mathrm{m}^{-1}$ (Figure 1b). A two-way nested ANOVA indicated significant differences among landforms and very highly significant $(\mathrm{P}<0.001)$ differences between material types nested within landform. Posterior tests indicated that materials from the Purga flat landform had significantly $(\mathrm{P}<0.05)$ higher ECe values than the Out of Pit Dump while materials from the other four landforms did not differ significantly $(\mathrm{P}>0.05)$. The ECe values of the wastes were greater than those of their associated soils at all landforms although these differences were significant only at Lane's and the Out of Pit Dumps. Over all records, the mean ECe of the soils was 1.33 while that of the wastes was $3.78 \mathrm{dS} \mathrm{m}^{-1}$.

Figure 2a plots the individual soil and waste samples on $\mathrm{pH}_{(\mathrm{H} 20)}$ and $\mathrm{ECe}$ scales; the $\mathrm{pH}_{(\mathrm{H} 20)}$ limits at five and eight indicate the approximate range within which plants are unlikely to suffer undue $\mathrm{pH}$-related nutrient stress. The approximate limits on the ordinate indicate the degree of salt tolerance that would be required for satisfactory plant growth on the different substrates. It is apparent that almost all soils fall within the nonstressful area while the properties of nearly all wastes indicate the considerable adaptation that is needed for plants to be able to grow satisfactorily on them.

ESP values ranged from 4 to a maximum of 57 over all three landforms tested (Figure 2b); the effect of landform was not significant $(\mathrm{P}>0.05)$, although material type was very highly significant $(\mathrm{P}<0.001)$. While the ESP of the wastes was consistently higher than that of the soils, this was only significant at the Out of Pit Dump. The mean ESP for all soils was 15 (std dev. 12, $\mathrm{n}=16$ ) while that of the wastes was 26 (std dev. 11, $\mathrm{n}=37$ ). In contrast, A horizon values of local natural soils were ca 1 in a tenosol and 6 in a sodosol although the B horizon of the latter soil was sodic (ESP $>12)$ at depth. 


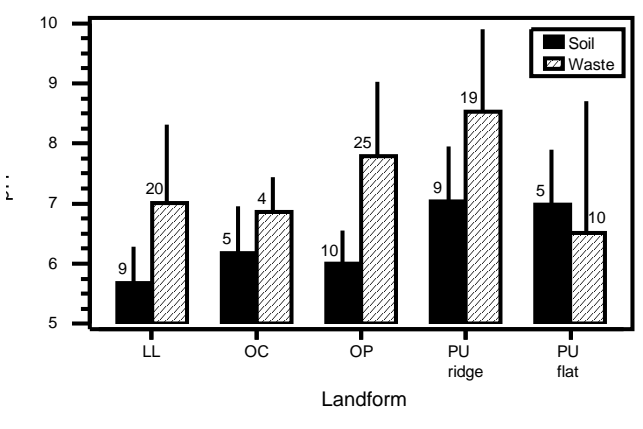

(a)

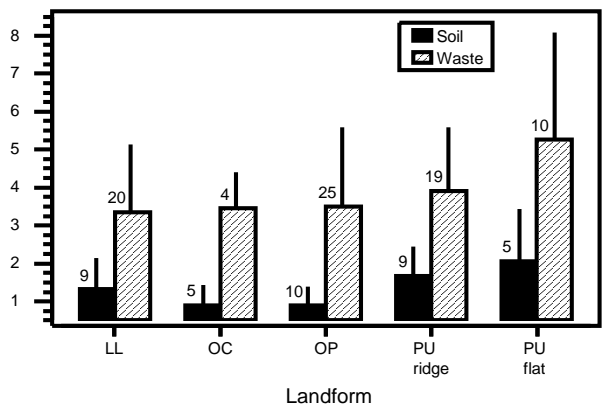

(b)

Figure 1 pH $\mathrm{pH}_{(\mathrm{H} 2)}$ (a) and ECe (b) of the soils and wastes at all landforms (means, std deviations and $\mathrm{n}$ )

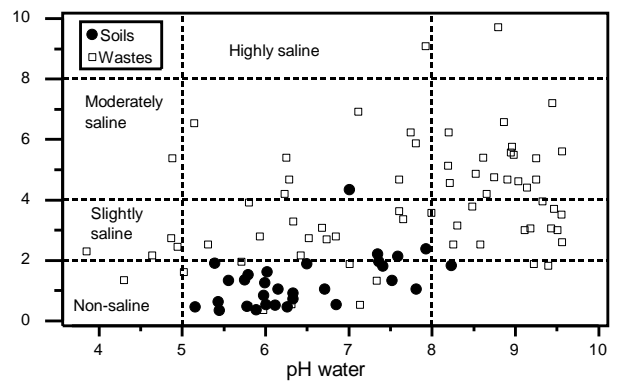

(a)

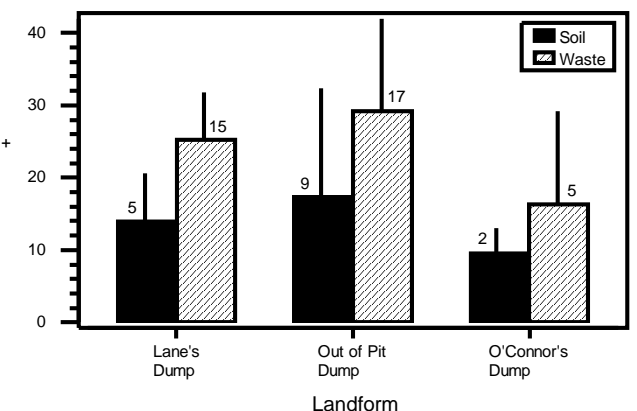

(b)

Figure 2 (a) Bivariate plot of $\mathrm{pH}_{(\mathrm{H} 20)}$ and ECe indicating stressful $\mathrm{pH}$ limits and approximate salt tolerances needed for satisfactory growth and (b) ESP values (means, std deviations, $n$ ) of the soils and wastes at three landforms

\subsubsection{Organic-matter-related properties and major nutrient elements}

The total $\mathrm{C}$ concentrations of the soils and wastes are presented in Figure 3a for all landforms. Excluding values for five samples rich in coal, concentrations in the soils ranged from 0.59 to $5.92 \%$ and in the wastes from 0.06 to $23.02 \%$. Values for the soils were similar to those reported for Australian sodosols and tenosols (Spain et al., 1983). An ANOVA of the differences among landforms and between soils and wastes indicated that differences among landforms were not significant $(\mathrm{P}>0.05)$ but that very highly significant $(\mathrm{P}<0.001)$ differences occurred between soils and wastes. Soils had significantly greater $\mathrm{C}$ concentrations than wastes at all landforms although the differences were only significant at Lane's Dump and at the Purga flat landform. The concentrations of $\mathrm{C}$ were significantly correlated with site age in both soils and wastes (respectively, $\mathrm{r}=0.367, \mathrm{P}=0.050, \mathrm{n}=29 ; \mathrm{r}=0.352, \mathrm{P}=0.004, \mathrm{n}=65)$.

Total $\mathrm{N}$ concentrations are presented in Figure $3 \mathrm{~b}$ for soils and wastes at all landforms. Concentrations in the soils ranged from 0.031 to $0.296 \%$ and fell within the range of local sodosols and tenosols; in the wastes, they ranged from 0.003 to $0.448 \%$. A nested ANOVA indicated that there were very highly significant $(\mathrm{P}<0.001)$ differences among landforms and between soils and wastes. Posterior tests indicated that Lane's Dump had a significantly $(\mathrm{P}<0.05)$ lower mean $\mathrm{N}$ concentration than all other landforms but that the remaining locations did not differ among themselves $(\mathrm{P}>0.05)$. Soils had higher $\mathrm{N}$ concentrations than wastes at all landforms although they were not significantly different $(\mathrm{P}>0.05)$ at the Out of Pit Dump and the Purga ridge landforms. The concentrations of $\mathrm{N}$ were not significantly correlated with site age in the soils but were in the wastes (respectively, $\mathrm{r}=0.119, \mathrm{P}=0.538, \mathrm{n}=29 ; \mathrm{r}=0.329, \mathrm{P}=0.006, \mathrm{n}=68$ ).

Readily-mineralisable $\mathrm{N}$ concentrations (Figure 3c) were moderate to low in the soils and very low in the wastes. No significant effect of landform was apparent although that for material type was very highly significant $(\mathrm{P}<0.001)$. Posterior tests indicated that concentrations of readily-mineralisable $\mathrm{N}$ were significantly greater in the soils than in the wastes at all three landforms. The readily-mineralisable 
$\mathrm{N}$ concentration of the soil cappings was similar to values in the upper A horizon $\left(12 \mathrm{mg} \mathrm{kg}^{-1}, 0-0.10 \mathrm{~m}\right)$ of a local tenosol although much lower than that of the upper A horizon of a local sodosol $\left(24 \mathrm{mg} \mathrm{kg}^{-1}\right.$, $0-0.10 \mathrm{~m})$.

The C:N ratios of most soils were similar to those occurring in Australian tenosols and sodosols (Spain et al., 1983) although they were substantially higher in the wastes. Figure $3 d$ presents the C:N ratios of the soils and wastes with five high outlying values removed because of coal in the profiles. Very highly significant $(\mathrm{P}<0.001)$ differences were apparent among landforms and highly significant $(\mathrm{P}<0.01)$ differences between material types. Mean values for the Out of Pit and Lane's landforms were significantly greater than those of the Purga landforms. At all sites except the Purga flat, values for soils were less than those of the underlying wastes although this was only significant at the Out of Pit site. The $\mathrm{C}: \mathrm{N}$ ratios of both the soils and wastes are strongly correlated with site age (respectively, $\mathrm{r}=0.503, \mathrm{P}=0.005, \mathrm{n}=29 ; \mathrm{r}=0.530, \mathrm{P}<0.001, \mathrm{n}=64$ ).

Total $\mathrm{P}$ concentrations (Figure 3e) in the Ebenezer materials are very low and did not differ significantly among landforms or between material types at any of the landforms. Mean total $\mathrm{P}$ concentration over all landforms and both materials was $0.023 \%$ (std dev. 0.014, $\mathrm{n}=98$ ); this may be compared with an estimated average total P concentration of $0.055 \%$ for Australian surface soils and $0.038 \%$ for sub-soils (Norrish and Rosser, 1983).

Available ('Olsen') P analyses were only conducted on materials from Lane's, the Out of Pit and O'Connor's Dumps. In contrast to total $\mathrm{P}$, very highly significant $(\mathrm{P}<0.001)$ differences occurred among landforms and between soils and wastes. Concentrations of Olsen $\mathrm{P}$ were low in the soils and even lower in the wastes (Figure 3f). These concentrations may be compared with $15 \mathrm{mg} \mathrm{kg}^{-1}$, a value below which pasture production is putatively limited by P deficiency (Gourley et al., 2007). Materials from Lane's Dump had greater P concentrations than the other two dumps. Concentrations were higher in all soils than in the underlying wastes although the differences were not significant $(\mathrm{P}>0.05)$ for the O'Connor's Dump materials.

\subsection{Fine root distributions}

Densities of fine ( $<2 \mathrm{~mm}$ diameter) roots of pasture plants were recorded at intervals down the walls of 26 pits distributed across the five landforms. The three pits at the Purga flat site and one at Lane's Dump were in areas that had only volunteer vegetation and had not been fertilised.

Median root density classes and their interquartile ranges are presented for the soils (Figure 4a) and the wastes (Figure 4b) of each landform. Similar median densities pertained among the soils except for lower densities at the three sites in the Purga flat area that had been topsoiled but possessed only a sparse volunteer vegetation. Root densities in the wastes were more variable with lowest values at the more recently established O'Connor's and Purga flat sites and greatest values at the longer-established Out of Pit Dump.

At revegetated sites in the rehabilitated landforms, fine roots extended to depths of more than $1.00 \mathrm{~m}$ in 16 of the 25 pits and were observed at $1.40 \mathrm{~m}$ at the bottom of one pit. Roots were distributed more shallowly in the recently established landforms: at one site in O'Connor's landform rehabilitated for only four months, roots extended to $0.3 \mathrm{~m}$ while in three pits at the Purga flat landform, maximum root depths ranged from 0.3 to $0.8 \mathrm{~m}$.

Ordinal logistic regressions were conducted of all 139 observations of root density values over the five landforms to test the relationships between root density class values and depth, age, material type (soil or waste) and their possible first order interactions as predictive factors. The records for the highest class of root density had only two observations and these were combined into the next lowest class; for purposes of the present analysis this class is defined as records having $>25$ roots per $100 \times 100 \mathrm{~mm}$ square of pit face. Depth was treated as having three levels: $0.0-0.49 \mathrm{~m}, 0.50-0.74 \mathrm{~m}$ and equal to or greater than $0.75 \mathrm{~m}$; site age was treated as having three levels: < 1 year; 1-2.9 years and 3 or more years. Material type was treated as having two levels: soil and waste.

Tests of the model terms indicated highly significant $(\mathrm{P}<0.01)$ effects of depth (Figure 5a), age (Figure 5b), a significant $(\mathrm{P}<0.05)$ effect of material type (Figure $5 \mathrm{c})$ and a highly significant $(\mathrm{P}<0.01)$ interaction between depth and age (Figures $5 \mathrm{~d}$ to $5 \mathrm{f}$ ). However, the interaction between age and material type was not significant $(\mathrm{P}>0.05)$. Goodness of fit tests indicated that there were no significant $(\mathrm{P}<0.05)$ departures from the fitted model. These results indicate that increasing profile depth categories are associated with higher predicted 
probabilities of lower root densities and that increases in age categories are likewise associated with increased predicted probabilities of a similar or higher root density class. It also indicates that decreases in predicted probabilities of being in the same or higher root density category occur in moving from soils to wastes. Figures $5 \mathrm{~d}$ to $5 \mathrm{f}$ illustrate the changing relationships that occur with depth in each of the three age categories.

(a)

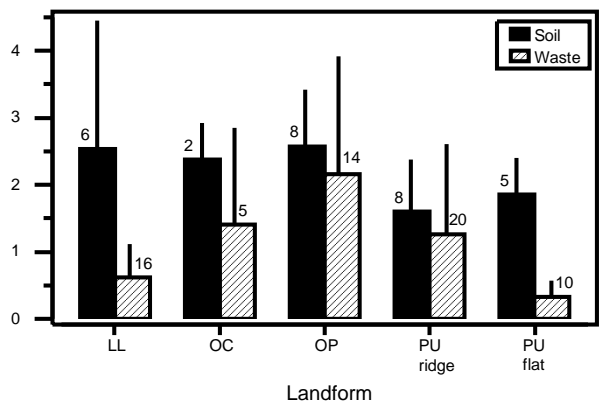

(c)

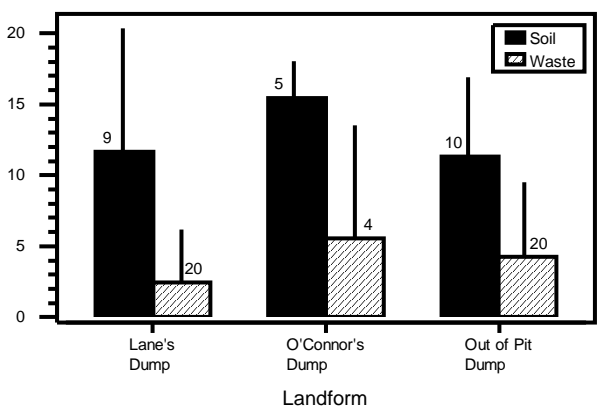

(e)

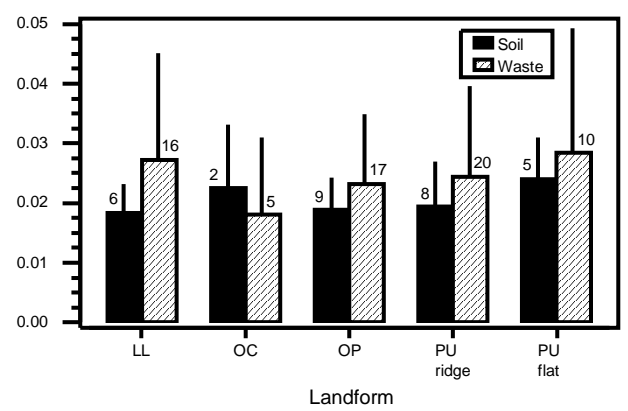

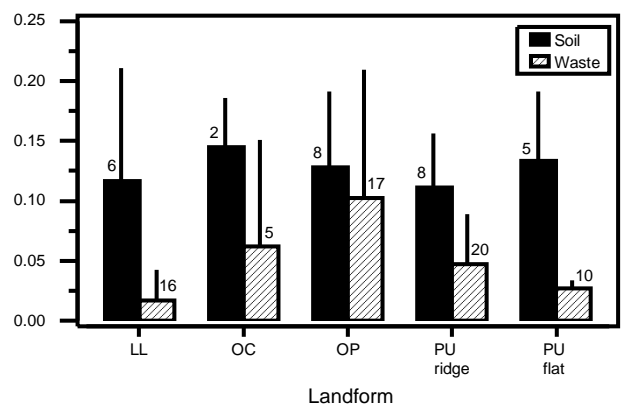

(b)

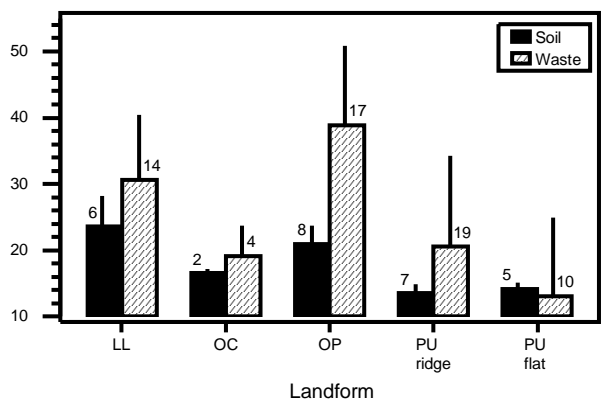

(d)

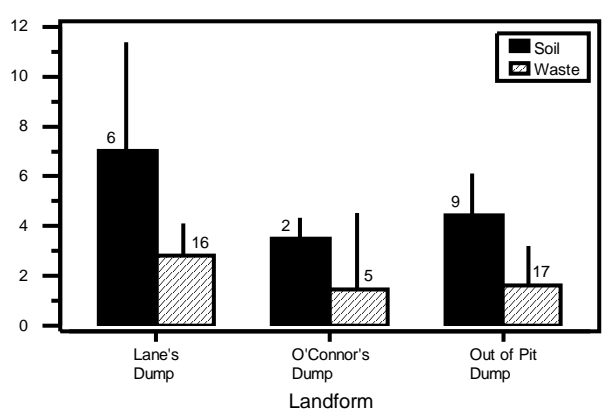

(f)

Figure 3 Chemical properties (means, std deviations, $n$ ) of the soils and wastes of rehabilitated waste rock dump landforms: (a) Total C; (b) Total N; (c) Readily-mineralisable N; (d) C:N ratio; (e) Total P; (f) Available (Olsen) P

\subsection{Distributions of mycorrhizal structures}

Figures $6 \mathrm{a}$ to $6 \mathrm{c}$ present the means and standard deviations of the percentages of fine roots occupied by mycorrhizal structures and the populations of AM fungal spores in the applied soils and upper wastes of each landform.

Mycorrhizal structures were present throughout the upper profiles and occurred in the wastes to more than one metre. Fine root colonisation percentage was distributed most shallowly and occurred at depths greater than one metre in only three pits (Figure 6c). Populations of AM spores were present in five of the 26 pits at depths greater than one metre. 

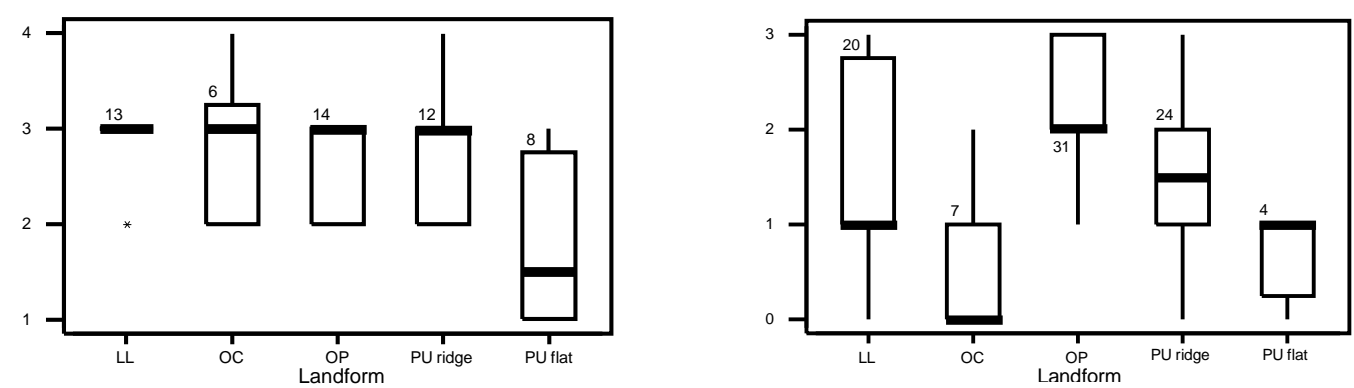

Figure 4 Medians (solid bar), interquartile ranges and outlying values for root density classes in soils (left) and the underlying wastes (right) of five landforms

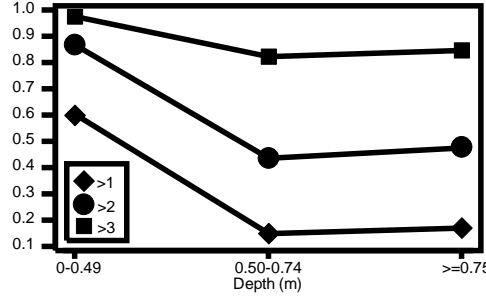

(a)

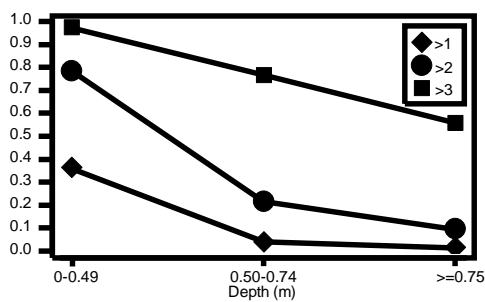

(d)

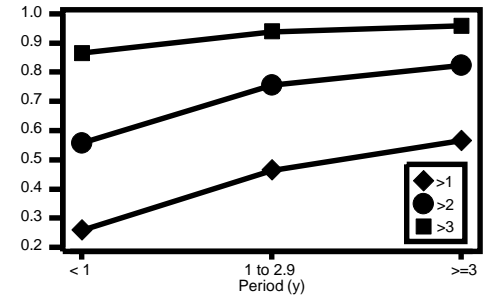

(b)

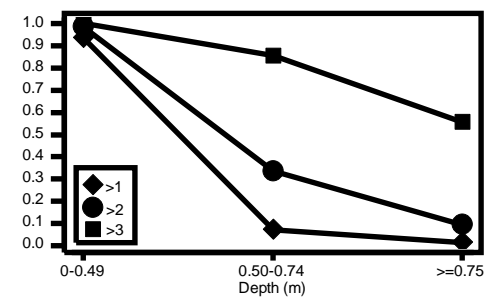

(e)

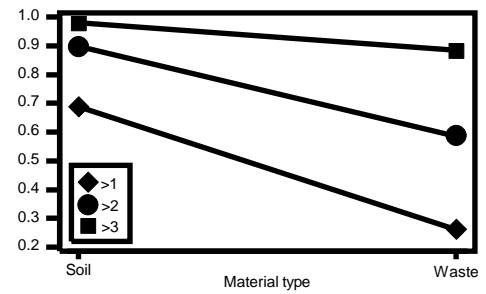

(c)

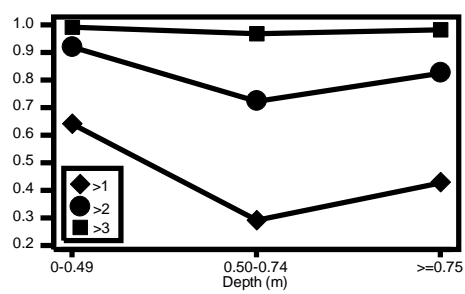

(f)

Figure 5 Ordinal logistic regression of variation in root distribution classes with (a) soil depth (b) period of rehabilitation, (c) material type and interactions between period and depth category (d) less than 1 year (e) 1-2.9 years (f) 3 years or greater: probabilities of remaining in the current category or above

Table 1 presents the results of a nested ANOVA of the percentage of fine root length colonised by mycorrhizal structures and the populations of AM spores in relation to the significance of differences among landforms and between soils and wastes (nested within landforms).

The percentages of the root lengths of the pasture plants colonised by AM fungal structures ranged from zero to $75 \%$ (Figure 6c). Higher values occurred in the soils than the wastes at most landforms although this was only significant at Lane's Dump. Roots were colonised to the maximum sampled depth range of 1.40 to $1.45 \mathrm{~m}$. Although little of the overall variation was explained, percentage root colonisation (ln transformation) declined significantly with depth (Equation 1):

$$
\text { Fine root colonisation }(\%)=1.824-0.016 . \text { depth, } \mathrm{R}^{2}=9.3 \%
$$

$$
\text { (se 0.004) }
$$

There were no significant $(\mathrm{P}<0.05)$ additional relationships with site age or through the separate identification of soils and wastes. 
Table 1 Nested ANOVA of AM fine root colonisation percentages and AM spore populations

\begin{tabular}{cccccc}
\hline Property & Factor & F & df & P & Transformation \\
\hline $\begin{array}{l}\text { AM fine root } \\
\text { colonisation }\end{array}$ & Landform & 2.86 & 4,112 & 0.027 & $\ln$ \\
& & & & & \\
\multirow{3}{*}{ AM spores } & Material & 3.17 & 5,112 & 0.010 & \\
& Landform & 4.81 & 4,117 & 0.001 & $\ln$ \\
& Material & 18.89 & 5,117 & $<0.001$ & \\
\hline
\end{tabular}

The Purga flat sites had the highest AM spore populations although they did not differ significantly from those of the Purga ridge area. None of the other four sites differed significantly in this respect. Except at O'Connor's Dump, the soil layer had significantly greater AM spore populations at all landforms than the underlying wastes. Small populations of spores were found at more than one metre depth and the deepest was observed in the depth range 1.40 to $1.45 \mathrm{~m}$. A clear decline of AM spore populations (ln transformation) occurred with depth, site age (years) and an identifier of soils and wastes (Equation 2):

$$
\mathrm{AM} \text { spore populations }=5.115-0.027 \text {.depth }-0.0841 \text {. age }-0.727 \text {. material, } \mathrm{R}^{2}=60.2 \%
$$

$$
\text { (se 0.004) (se 0.026) (se 0.274) }
$$

\section{Discussion and conclusions}

In designing rehabilitation works at Ebenezer and other mines, it is important to assess the probability of ongoing successful long term ecosystem development by defining substrate properties in relation to putative plant tolerance of extreme $\mathrm{pH}$, salinity, sodicity and nutritional constraints. Soils are a valuable and somewhat scarce resource on most mines and mean applied soil thickness averaged $0.31 \mathrm{~m}$ at Ebenezer. It was therefore expected that, for successful site phytostabilisation, roots would need to be able to penetrate the wastes deeply enough for them to access sufficient water and nutrients to support long-term growth. Limitations to gaining access to such reserves would be likely to constrain long-term plant success and potentially expose the landform surfaces to accelerated erosion.

While most are sodic, the soil capping materials used at Ebenezer largely fall within the limits of $\mathrm{pH}$ and salt tolerance of plants not possessing special adaptations to these conditions. In contrast, the wastes are stressful growing media in several respects: half the wastes lie outside the $\mathrm{pH}_{(\mathrm{H} 2 \mathrm{O})}$ range of five to eight and are sufficiently saline that successful growth and development on these materials is considered to require the use of plants with at least a moderate degree of adaptation to salinity (Marcar and Crawford, 2004). Almost all wastes are highly sodic and a considerable number are saline-sodic; it is likely that combinations of these factors and extreme $\mathrm{pH}$ and nutrient stress will exacerbate overall plant stress beyond that due to the individual factors alone. It is further unknown if these effects are simply additive or whether interactions occur to increase or reduce their overall effects.

Many post-mining materials have a limited capacity to provide an adequate supply of plant nutrient elements for satisfactory growth. This may be due to low absolute concentrations or because the $\mathrm{pH}$ falls outside the range within which available forms of these elements occur. Nitrogen and P limitations are perhaps the most common limiting elements at Ebenezer Mine although others may also be important (Tibbett et al., 2010). At Ebenezer, $\mathrm{N}$ concentrations in the soil cappings are moderately low although total $\mathrm{P}$ concentrations are very low in these soil materials and mine wastes in comparison with most Australian soils (see also Brown and Grant, 2000). Similarly, low Olsen $P$ values indicate that $P$ deficiency generally limits pasture production.

Despite the unfavourable chemical environment of the substrates in which they were growing, roots of the pasture plants grown on the site regularly extended to more than one metre deep, with few observed at $1.40 \mathrm{~m}$. In this, they are similar to the generalised root depth distributions for grasses in natural environments reported by Jackson et al. (1996); it is therefore apparent that they could readily tolerate the chemical and physical conditions pertaining in the upper wastes. Clear differences exist with depth and material type and it is suggested that root colonisation of the overlying soils occurs rapidly but that colonisation of the underlying wastes is slower, requiring longer time periods to develop. 


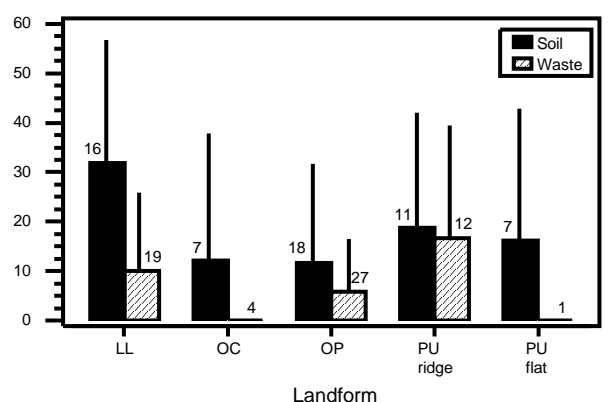

(a) Fine root colonisation $\%$

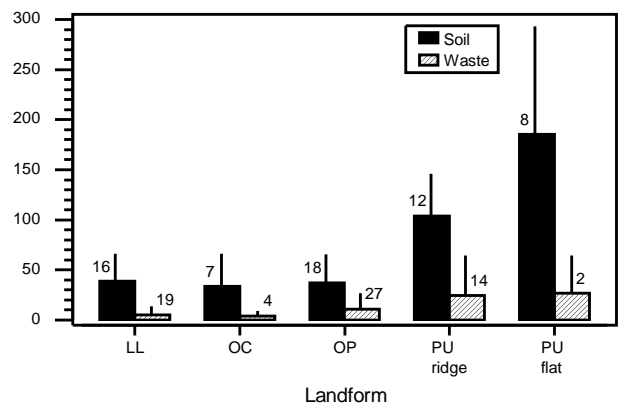

(b) AM spore populations

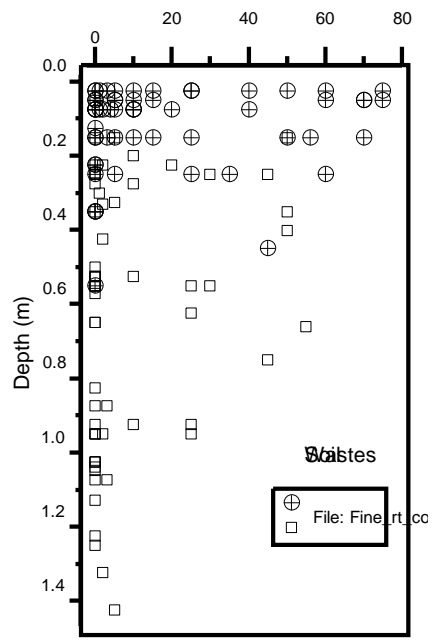

(c) Fine root colonisation with depth

Figure 6 Incidences (means, std deviations, $n$ ) of mycorrhizal structures in the soils and wastes of five rehabilitated landforms at Ebenezer Mine: (a) percentage colonisation of fine roots; (b) AM spore populations per $50 \mathrm{~g}$ dry soil; (c) Depth distributions of the percentages of fine roots occupied by AM fungal structures, combined over five landforms

The consistently wide distributions of mycorrhizal structures in the soils and at depth in the wastes indicate that plants in all except the most recently established sites have been successfully colonised. The soils, and particularly the waste materials, have low $\mathrm{P}$ availability for pasture systems and such low concentrations of $\mathrm{P}$ have been shown to promote mycorrhizal colonisation in Australian pastures (Ryan et al., 2000; Ryan and Tibbett, 2008). While the community of arbuscular mycorrhizal species has not been elucidated in this study it is clear that, as a functional group, these fungi have established in all materials in high numbers. Given the range of materials and the putatively hostile nature of many of the wastes, it is remarkable how well mycorrhizal fungi have colonised all materials. As these fungi likely confer survival and growth advantages in the stressful post-mining soil and waste environment, it is encouraging to report such strong population counts in relatively early years of rehabilitation.

There is some evidence of incipient pedogenic change in the rehabilitated landforms. These include increases in $\mathrm{C}$ and $\mathrm{N}$ concentrations in the wastes with rehabilitation period although the $\mathrm{C}: \mathrm{N}$ ratio was found to be similarly increasing. In contrast, there is evidence for strong $\mathrm{P}$ limitation to plant growth which may eventually lead to surface instability. In the long term, it is ongoing soil development to depth under the influence of a productive plant cover that is likely to sustain the stability of these landforms.

\section{Acknowledgements}

We thank Ms Sue Joyce for her able technical assistance in this project. 


\section{References}

Anon. (2001) Grasses for mine rehab, Tropical Grassland Society News and Views, 17(4), pp. 1-3.

Bevege, D.I. (1968) A rapid technique for clearing tannins and staining intact roots for detection of mycorrhizas caused by Endogone spp. and some records of infection in Australasian plants, Transactions of the British Mycological Society 51, pp. 808-810.

Brown, G.M.C. and Grant, C.D. (2000) Nutrient status of pasture ecosystems established on rehabilitated overburden and topsoil sites in the Hunter Valley, New South Wales, Australian Journal of Soil Research 38, pp. 479-491.

Bureau of Meteorology (2011) http://www.bom.gov.au/climate/averages/tables/cw_014508.shtml.

Gianello, C. and Bremner, J.M. (1986) Comparison of chemical methods of assessing potentially available nitrogen in soil, Communications in Soil Science and Plant Analysis 17, pp. 215-236.

Gourley, C.J.P., Melland, A.R., Waller, R.A., Awty, I.M., Smith, A.P., Peverill, K.I. and Hannah, M.C. (2007) Making better fertiliser decisions for grazed pastures in Australia, Victorian Department of Primary Industries, Melbourne, Victoria, $18 \mathrm{p}$.

Isbell, R.F. (2002) The Australian soil classification, revised edition, CSIRO Publishing, Collingwood, Victoria, 152 p.

Jackson, R.B., Canadell, J., Ehleringer, J.R., Mooney, H.A., Sala, O.E. and Schulze, E.D. (1996) A global analysis of root distributions for terrestrial biomes, Oecologia 108, pp. 389-411.

Kulmatiski, A., Beard, K.H., Stevens, J.R. and Cobbold, S.M. (2008) Plant-soil feedbacks: a meta-analytical review, Ecology Letters 11, pp. 980-982.

Loveday, J. (1974) Methods for analysis of irrigated soils, Commonwealth Bureau of Soils, Technical Communication No. 54, Commonwealth Agricultural Bureau, Canberra, 208 p.

Marcar, N.E. and Crawford, D.F. (2004) Trees for saltland, Rural Industries Research and Development Corporation, ACT, $140 \mathrm{p}$.

McDonald, R.C. and Isbell, R.F. (1990) Soil profile. Australian Soil and Land Survey Field Handbook, 2nd edition, reprinted, ACLEP, Canberra, pp. 103-152.

Norrish, K. and Rosser, H. (1983) Mineral phosphate, in Soils: an Australian viewpoint, Division of Soils, CSIRO, CSIRO, Melbourne and Academic Press, London. pp. 335-361.

Rayment, G.E. and Higginson, F.R. (1992) Australian laboratory handbook of soil and water chemical methods, Inkata Press, Melbourne, $330 \mathrm{p}$.

Ryan, M.H. and Tibbett, M. (2008) The role of arbuscular mycorrhizal fungi in organic farming systems, Organic Crop Production, H. Kirchmann and L. Bergström (eds) Springer-Verlag, Netherlands, pp. 189-229.

Ryan, M.H., Small, D.R. and Ash, J.E. (2000) Phosphorus controls the level of colonisation by arbuscular mycorrhizal fungi in conventional and biodynamic irrigated dairy pastures, Australian Journal of Experimental Agriculture Vol. 40, pp. 663-670.

Simon-Coinçon, R., Spain, A.V. and Milnes, A.R. (2003) Landform processes in the post coal mining landscape, Bowen Basin, Australia. A geomorphological approach, International Journal of Surface Mining, Reclamation and Environment 17(1), pp. 20-50.

Spain, A.V., Isbell, R.F. and Probert, M.E. (1983) Organic matter contents of Australian soils, in Soils: an Australian viewpoint, Division of Soils, CSIRO, CSIRO Melbourne and Academic Press, London, pp. 551-563.

Spain, A.V., Tibbett, M. and Worrall, R. (2010) Rehabilitation studies at the Ebenezer Mine, Ipswich, Queensland 1998 to 2007. Volume I: The soils and near-surface wastes of selected rehabilitated waste rock dumps at Ebenezer Mine, Report to Idemitsu Australia Resources Pty Ltd, Brisbane, Centre for Land Rehabilitation, The University of Western Australia, Report Reference: CLR-10-01-C/ CSIRO Earth Sciences and Resource Engineering, Report: EP106663 (ISBN: 978-1-74052-198-7), 185 p.

Tibbett, M., Spain, A.V., Tapsall, B. and Edmonds-Tibbett, T.L. (2010) Rehabilitation studies at the Ebenezer coal mine, Ipswich, Queensland - 1998 to 2007. Volume III: Nutritional constraints to plant growth on six diverse materials, Queensland, University of Western Australia, Centre for Land Rehabilitation, CLR Report Ref: CLR10-03-C, $32 \mathrm{p}$.

Tommerup, I.C. (1992) Methods for the study of the population biology of vesicular-arbuscular mycorrhizal fungi, Methods in Microbiology, 24. Techniques for the study of mycorrhizas, J.R. Norris, D.J. Read and A.K. Varma (eds), Academic Press, London, pp. 23-51.

Weiersbye, I.M. (2007) Global review and cost comparison of conventional and phytotechnologies for mine closure, Proceedings Second International Seminar on Mine Closure (Mine Closure 2007), A.B. Fourie, M. Tibbett and J.V. Wiertz (eds), 16-19 October 2007, Santiago, Chile, Australian Centre for Geomechanics, Perth, pp. 13-30. 